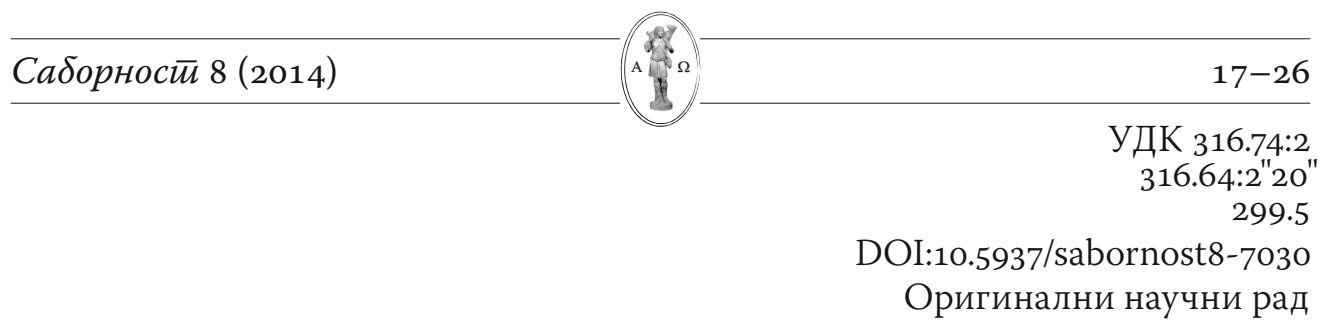

\title{
Зоран Крстић"
}

Универзитет у Београду, Православни богословски факултет, Београд

\section{Могућности хришћанског теолошког мишљења у постмодерности}

\begin{abstract}
: У овом есеју аутор покушава да одговори на питање постављено у наслову - да ли је данас уопште могуће теолошки промишљати одређене проблеме са хришћанских позиција због врло јаких и често неприметних наноса менталитета постмодернистичке религиозности. После почетног наглашавања тешке позиције хришћанског теолога, даје се увид у европске секуларизацијске и десекуларизацијске процесе и „повратак светога“ у јавну сферу. Тај се увид остварује резултатима истраживања религиозности, како у Европи, тако још детаљније кроз резултате најновијих истраживања религиозности у Србији. Аутор сматра да постоје одређени разлози за оптимизам, уколико се пореди садашња ситуација са ситуацијом од пре неколико деценија, али да, генерално, морамо бити врло опрезни у сопственом оптимизму. Постмодернистичка религиозност не значи повратак на традиционалне форме религиозности, па чак не значи ни повратак традиционалним европским црквама. Као карактеристике те религиозности, аутор наглашава неинституционалност и нарцисоидност, уз постављање питања какав нам се бог вратио. У закључним размишљањима се наглашава да савремена ситуација намеће питање о Богу као основно теолошко питање, али и да теологија не треба да буде само говор о Богу, већ Божији іовор релевантан за конкретну људску егзистенцију.
\end{abstract}

Key words: теолог, секуларизација и десекуларизација, религиозност и хришћанска вера, социографија, постмодернистички религиозни менталитети.

Д;

убоко сам уверен да савремена друштвена стварност са својом променљивошћу, плурализмом и специфичном свешћу и менталитетима представља такво искушење за Цркву какво Она није имала у досадашњој историји. Таква ситуација не може, по логици ствари, да заобиће ни хришћанску теологију. И она се, као реч о вери, као наука о вери, нашла пред питањем своје црквене релевантности, а још више, заједно са својим предметом, самом вером, пред крупним питањем друштвене релевантности. У клими готово генералног порицања сваке трансцендентности и свођења

zorank62@gmail.com 


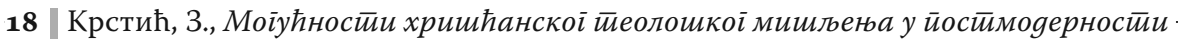

целокупне антрополошке проблематике искључиво на иманентно, сваки се савремени теолог може запитати о смислу сопствених теолошких прегнућа.

Да ли је осећај избачености из матице живота можда најјачи и најгорчи осећај који окуша савремени теолог замишљен над својом службом? Живот промиче поред нас, шарен, буран, док ми, изгурани на друштвене маргине, покушавамо да том свету кажемо нешто, по нашем мишљењу, не само важно већ суштинско, а нико се на наше речи не осврће. Никога „није брига" и свако је заузет сопственим свакодневним животним проблемима и мислима у којима је ретко хришћански Бог и на која хришћанска теологија, обично, нема одговоре. И овде би и овај оглед могао да се заврши песимистички постављеним питањем - коме још теологија треба. Међутим, такво питање би било на свом месту када би се око нас ширило бескрајно море атеизма у коме би се и свака теологија, па и хришћанска, утопила. Насупрот томе, ми око себе видимо, а и емпиријска истраживања то потврђују, море, не отпадништва од Бога, већ море религиозних веровања у свим облицима и свих интензитета какво никад пре није постојало у историји. Савремени човек је исто, а највероватније још и више религиозан него икада у историји, што опет емпиријска истраживања потврђују. Шта онда ту, питамо се, није у реду — теологија, Бог, савремени човек и његов свет или нешто четврто?

Као што видимо, питања се роје и роје и свако заслужује адекватан одговор. Али, ипак, у овој нашој једначини са више непознатих ограничићу се, не због важности већ према сопственим интересовањима, на питање религиозне свести данашњег човека. Како се она формирала, која су њена обележја и како друштвени, постмодернистички контекст на њу утиче и обрнуто.

\section{Оптимистичко виђење стварности}

Радикална философска, социолошка, психолошка наука 19. и почетка 20. века у личностима Маркса, Ничеа, Фојербаха, Фројда, па преко „Бечког круга“, радикалних критичара сваке метафизике, предвиђала је скори крај религије као друштвеног феномена. То се посебно односило на хришћанство живљено у традиционалним европским црквама. Сви они су се ослањали на готово догматску модернистичку веру у прогрес и људски ratio, који ће обесмислити и учинити сувишним свако религијско веровање. Друштвени токови, а посебно они после Другог светског рата, су изгледали незаустављиви и давали им за право. Растуће друштвено благостање западних друштава се чинило да потврђује њихове хипотезе и да је баш оно, само благостање или његово скоро али извесно очекивање, најбоља клима у којој религијска веровања копну и ишчезавају. На истоку Европе је место благостања заузела атеистичка тоталитарна државна идеологија опет, како је изгледало, са истим резултатима. Религија, па са 
њом и хришћанство, нестаје или ће убрзо нестати милом или силом државног апарата. Овај опис је свима добро познати опис секуларизацијског процеса у европским друштвима, који је свој врхунац и на Истоку и на Западу имао у деценији шездесетих година прошлог века. Протестантска теологија, затим пастирска социологија, па тек за њима се и социологија религије почела теоретски бавити секуларизацијом европских друштава, али, до дана данашњег, без сагласности у погледу одређења ${ }^{\mathbf{1}}$ и обима самог процеса. ${ }^{2}$ На практичном плану ствари су биле далеко једноставније. Пад верске праксе у црквама Европе је најлакше било изразити бројкама. „Показало се да је секуларизација захватила сва подручја традиционалног хришћанства." (Jukić, 1997, стр. 193) Прва књига која је током Другог светског рата уздрмала западни хришћански свет је била књига са питањем у наслову: „Француска - земља мисија?", коју су 1943. објавили Godin и Daniel, указујући на чињеницу пада верске праксе у Француској. На основу тих почетних истраживања, Gabriel Le Bras и Bulard су после рата започели велика емпиријска истраживања стварног стања верске праксе и која су недвосмислено указивала да, иако хришћанство није нестало, хришћанске цркве су почеле да се празне. Црквено активних верника је бивало све мање. Истраживања спроведена, рецимо, средином 80-их су показала да 82\% Француза сматра себе вернима, док свега 13\% редовно учествује у недељној миси. У Енглеској 6о\% изјављује да припада Цркви, а $3 \%$ активно учествује у црквеном животу. У Италији се тај број пење на 20\%, а у Португалији на 30\%. (Jukić, 1997, стр. 193)

Сва та многобројна истраживања спроведена током последњих деценија недвосмислено потврђују „дијагнозу да је, пре свега, конвенционална религија у кризи, да се одваја од друштва, да се из њега повлачи или, с друге стране гледано, да људи све мање своје конкретно свакодневно понашање моделују према религијским веровањима, етичким порукама или религиозном понашању“. (Благојевић, 2008а, стр. 278)

Треба, међутим, нагласити да европски простор није религијски јединствен и да постоје велике разлике у веровањима и пракси од државе до државе, од регије до регије, а посебно према, у њима, превладавајуће хришћанске конфесије, односно да ли је средина претежно католичка или православна, мешовита или претежно протестантска где се, у овим последњим, и показују највећи проценти црквене апстиненције. ${ }^{3}$

Такође треба нагласити да индикатори црквене праксе које највише користим нису једини у процени узнапредовалости процеса секуларизације у некој средини. Постоји читав низ индикатора који се користе у религијској социографији. Поменућу да секуларизацијски процеси могу да се прате на

\footnotetext{
1 Види неке предлоге код Мандзаридис, 2004, стр. 129 и даље.

2 Види Благојевић, 2013, стр. 12 и даље.

3 Види Grace, 2005, стр. 19 и даље.
} 
основу разлике у односима село - град, кроз селективност прихватања религијских веровања, па узраст и пол испитаника, број свештеника у једној средини и много других до сада већ коришћених индикатора. ${ }^{4}$ Све нам ово показује сложеност религијског феномена у савременој Европи, који тражи изнијансирани приступ, а не трпи више традиционални еn block приступ.

Друштвена струјања везана за религијски феномен и процес секуларизације су доживела почетком 70-их година на Западу ни од кога очекивани обрт, док се на Истоку то десило у пуном обиму после пада комунизма у деценији 9о-их прошлог века. Од тог периода се у теорији говори о свима добро познатом „повратку светог“, „освети Божијој“, десекуларизацији друштва, повратку религије у јавну друштвену сферу и сл. Сва поменута одређења имају за циљ да скрену пажњу на значајно промењени и повећани значај религијског феномена у савременом друштвеном животу.

Оно што нас, свакако, највише занима јесу резултати емпиријских истраживања спроведених у нашој земљи и њихово, евентуално, теолошко вредновање.

У ту сврху ће нам, најпре, послужити последње емпиријско истраживање из 2013. године, које је спровела група истраживача на челу са др Мирком Благојевићем, а на репрезентативном узорку од 1056 студената треће године, и то 854 са државних и 202 са приватних универзитета у Србији, а затим и она најранија проф. Драгољуба Ђорђевића из Ниша.

Проф. Драгољуб Ђорћевић је 1982. године спровео у доминантно православном, Нишком региону истраживање религиозности становништва и закључио да је процес секуларизације на православно хомогеном простору пустио дубоке корене и узео највише маха у односу на све остале конфесионалне просторе. Неки видови религиозне свести и религиозне праксе су, према Ђорђевићевим истраживањима, дошли до ишчезнућа. (Ђорђевић, 1984) До сличних резултата је поменути професор дошао и 1985. године, овог пута истражујући религиозност нишких студената. Упоредимо сада резултате до којих је дошао Благојевић 2013. са резултатима Ђорђевића из 1985. године. Подсећамо да су и једно и друго истраживање рађени на узорку студентске популације. Изнећемо само оне податке који су потребни за нашу анализу.

Према индикатору конфесионалне идентификације, студенти се као православни изјашњавају 2013. у проценту од 79,1\%, а 1985. године - 65,6\%. Према личној религијској самодекларацији, дакле, као религиозни и припадници традиционалне верске заједнице: 2013. године - 55,8\%, 1985. године - 2,9\%; као религиозан и не припада ниједној верској заједници: 2013. године - 11,4\%, за 1985. немамо податак; као нерелигиозни: 2013.

4 Види Jukić, 1997, стр. 196 и даље. 
године - 6,9\%, 1985. године - 51,2\%; као убеђени атеиста: 2013. године 5,6\%, 1985. године - 29,7\%. Дакле, 2013. је 69,2\% религиозних студената наспрам 2,9\% 1985. и 18\% нерелигиозних 2013. наспрам 80,9\% 1985. године. (Благојевић, 2013, стр. 11 и даље) Резултати истраживања Хришћанског културног центра из 2010. године на узорку опште популације од 1219 испитаника су показали сличне проценте: 67, 3\% верује да Бог постоји и 20,4\% да постоји нека врста силе која може бити Бог. (Релиїиозносй y Србији 2010., 2011, стр. 207)

И само на основу ових података може се, чини ми се, с правом подржати десекуларизацијска теорија, јер су људи не само у нашем друштву већ и широм Европе, а нарочито широм света, религиозни у врло високом проценту. Искористићу и ја већ много пута цитирано мишљење једног од најзначајнијих савремених социолога религије Питера Бергера, који је од поборника секуларизацијске теорије током времена и након неочекиваних друштвених обрта изнео следећи став:

„Данашњи свет, уз неке изузетке [...] је жестоко религиозан као што је одувек и био, а у неким подручјима је чак и више него раније. Ово значи да је читава литература коју су стварали историчари и друштвени научници, који су прилично комотно објавили 'секуларизацијску теорију', у суштини погрешна." (Berger, 2008, стр. 12)

За наше друштво се, такође, може закључити да се „данас православно хомогено српско подручје више не може препознати као подручје у коме су обреди актуелне религијске природе изузетно еродирани а становници у 'ঠегу' од религије и цркве“ (Благојевић, 2008б, стр. 251).

Разлога за оптимизам чини се да има. Међутим, и нажалост, то није све што се теоретски може рећи и емпиријски поткрепити у вези са „повратком светог“. Са становишта хришћанске теологије и традиционалних цркава Европе много је значајнији одговор на питање какав нам се Бог вратио и на основу тога би следило и питање:

\section{Да ли је рано за оптимизам?}

Ако бисмо погледали и друге резултате истраживања, а који се тичу религијске праксе, затим индикаторе верске догматике и сл., дакле, индикаторе који се тичу суштинских манифестација хришћанске вере а не само религиозности уопште, слика се драстично мења, што нам и сопствено искуство говори и чега смо сви ми потпуно свесни.

Поменућу само један резултат истраживања религијске праксе испитаника. Студенти у истраживању из 2013. године бар једном месечно учествују у литургији у проценту од 9,2, неколико пута годишње 35,7\% и никада 51\% (Благојевић, 2013, стр. 51); општа популација 2010. године 17,1\% бар једном месечно, неколико пута годишње 40,9\% и никада 42\% (Благојевић, 2013, стр. 51). 


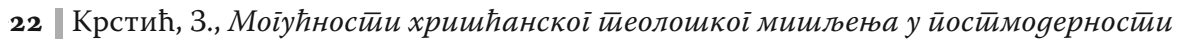

Овако велика разлика у процентима између самодекларисаних религиозних испитаника и оних који редовно учествују у литургијском животу је очигледан знак да треба да будемо врло опрезни у сопственом оптимизму. Он је оправдан уколико као параметар узмемо стање из 1985. кад истраживања показују проценат од о,3\% учествовања студентске популације у литургијском животу бар једном месечно (Благојевић, 2013, стр. 51), али не и генерално. Ово нас подсећа да треба да се вратимо питању какав нам се бог вратио, односно да се вратимо анализи религијске ренесансе са хришћанске тачке гледишта.

Као полазна тачка треба да нам послужи констатација да самодекларисана религиозност и хришћанска вера нису исто. Та се чињеница често занемарује у црквеним круговима када из најразличитијих друштвених, обично не из еклисиолошких разлога, покушавамо да због сопственог друштвеног потврђивања, а понекад и самозадовољства, тријумфалистички истакнемо овај аргумент високог процента религијске и конфесионалне самодекларације. Данашња постмодернистичка религиозност у својој ренесанси не значи повратак на традиционално, у Цркви утемељено и живљено хришћанство. Она, по речима једног савременог римокатоличког теолога, „nosi u sebi svašta, a katkada baš ništa zajedničkoga s autentičnim kršćanskim iskustvom stvarnosti“ (Matulić, 2009, стр. 780). И ето одмах задатка за хришћанску теологију да не само нагласи шта није аутентично хришћанство већ да каже и шта јесте хришћански етос пред изазовом постмодернистичке религиозности. Религиозност је шири појам од хришћанске вере, али су кроз, пре свега, средњовековну историју традиционалне цркве у Европи успевале да држе под контролом, мање или више успешно, целокупни религијски феномен, и то захваљујући различитим друштвеним функцијама које су имале, а превасходно својом политичношћу. Такве претензије више нису могуће, и то због слабљења, а понекад и потпуног ишчезавања појединих друштвених функција, тако да то доводи до, с једне стране, неконтролисаног и слободног бујања религијског феномена, а с друге, његовог све већег и даљег одвајања од хришћанске вере. То је наша постмодернистичка дијагноза која нас обавезује да као теолози дамо објашњење уводне тврдње да је она потенцијални противник хришћанске вере каквог она до сада није имала у историји, као и да дамо одговор на питање из наслова да ли она оставља простор за хришћанско промишљање и разумевање стварности.

Од многих карактеристика постмодернистичке религиозности и савремене епохе, јер свака историјска и друштвена епоха ствара и свој карактеристични тип религиозности, морам се определити само за одређене на које посебно желим да скренем пажњу.

Мишел Лакроа наводи 4 начела религијске синтезе Новог доба: 
„Четврто начело на коме се заснива религијска синтеза Новог доба јесте одбацивање институционализованих цркава. Ново доба пребацује црквама да су заборавиле прави смисао речи религија (повезати): оне више не служе стварању веза међу људима и изгубиле су из вида јединство човека и божанства, јер су се окренуле апстрактном и осиромашеном културном животу." (Lakroa, 2001, стр. 38)

Овако размишљајући, савремени човек се ослобађа институционалне цркве, као што је уопште постмодернизам „алергичан“ на све велике институције попут државе и породице, на пример, и у својој разочараности тим истим институцијама постаје нешто попут „плутајућег верника“ (Lakroa, 2001, стр. 38) какве и окупља Ново доба. Групација религиозних која бележи највећи пораст у Европи је она без конфесије или, како они себе називају, „слободни од конфесије“ (Kaufman, 2оо3, стр. 8), а највећу тешкоћу за одређење њихове религиозности представља немогућност да се открије и обухвати шта јој све припада. То је једно бескрајно море веровања различитог порекла и све то без икакве уједињујуће институције, а често и без елементарне логике. Међутим, основне теме и веровања постмодернистичке религиозности

„готово нечујно и несвесно умеју да се споје и са хришћанским веровањима и са научним дискурсом, тако да Ново доба, по много чему, постаје невидљива религија коју појединци, суочени са тегобом и тескобом живота у технолошкој ери, нехотице интериоризују као врсту могућег спасења у беспућу у коме се налазе. Нехотице, јер многи постулати Новог доба могу да се открију код оних који верују да су правоверни хришћани, као и код оних који су уверени да уопште не верују." (Ђорђевић, 2001, стр. 95)

И ето те поменуте опасности. У историји смо обично имали јасно профилисане противнике хришћанства, а сада се по први пут, како ми се чини, сусрећемо са једним невидљивим. Прави и суштински проблем се не налази у детектовању страних наноса на нивоу идеја, већ на нивоу конкретне личности, у чијем искуству и доживљају је врло тешко повући границе између тзв. нове духовности и аутентичне хришћанске духовности. Нова религиозност је стање свести, менталитет савременог човека који се формира и шири, пре свега, средствима масовне комуникације, градећи и ширећи једну глобалну мрежу, и то кроз омиљене теме попут личне среће, индивидуалног успеха, здравља подигнутог на ниво светости, младости, лепоте и много весеља и уживања у животу. Једном речју, „čovek postmoderne je erotično neutaživ u svojoj narcističkoj žeđi za vlastitom ispunjenošću i ostvarenjem“ (Mardešić, 2007, стр. 451). Тако се, на крају, намеће закључак да је религиозност постмодерне у својој главној струји заправо религијски индивидуализам, у коме лични елемент искуства нарцисоидног типа односи превагу над свим осталим, без икаквог додатног критеријума у процени тог искуства. Кад говоримо о личној срећи као врховном идеалу, онда је јасно да се она мора остварити hic et nunc, а не 
одложено, а посебно не у есхатону. Неискусном пастиру све ово може да заличи на хришћанство, а заправо - кад он говори о спасењу, савремени човек чује „здравље“, кад говори о обожењу, он чује „животна срећа“, кад говори о Васкрсењу, он чује „реинкарнација“, а кад каже „жртва“, савремени човек тада затвара свој ум и срце. Зарад остварења тог неухватљивог циља сопствене животне среће савремени човек „троши“, „конзумира“ религију као што конзумира и све остало, почевши од самог Бога који је за њега само „najdublje iskustvo sopstvenog bića“ (Mardešić, 2007, стр. 451) и ништа више од тога.

\section{Закључна размишљања}

На основу до сада изнетих података и увида у актуелно стање религиозности, неодољиво ми се намеће једна констатација - и савремени, постмодернистички човек, баш као и сваки до сада, тражи Бога. Тражи га по беспућима и лавиринтима друштва и културе, али и у тами сопственог бића. Овог пута он је потпуно сам јер је одбацио све велике институције, укључујући и цркве, и све велике идеологије 20. века које су га изневериле. Постмодерност се може одредити као криза свих идеја модерности, али на основу тога и постмодернистичка религиозност као криза религиозности. Она је продукт свести човека научно-технолошке цивилизације који покушава да испуни духовну празнину, а да истовремено и не угрози савремену културу чије је чедо. То је покушај својеврсног компромиса духовности, па и хришћанске, и светског духа. Не треба бити много паметан па закључити да, сходно ситуацији, и основна брига и тема савремене теологије треба да буде баш хришћански Бог који шаље свога Сина због људи, међу људе и који је близак људима. Можемо се даље запитати да ли је могућа теологија без Бога. Одговор на ову терминолошку контрадикцију би можда и могао да буде позитиван уколико би теологија остала само реч, само говор о Богу који може да буде неискуствен, непроживљен, те стога и неаутентичан. Садашње стање религиозности је истовремено и критика такве теологије. Данашња потреба је, сматрам, да теологија, пре свега, буде реч Божија, Божији іовор измученом и усамљеном човеку у оковима економске научно-технолошке цивилизације, који је релевантан за конкретну људску егзистенцију. 


\section{Литература}

Berger, P. (2008). Desekularizacija sveta - preporod religije i svetska politika. Novi Sad: Meditteran Publishing.

Благојевић, М. (2008а). Религиозна Европа, Русија и Србија: јуче и данас. У Филособија и ярушйво, 1, 275-294.

Благојевић, М. (2008ठ). Религиозна Европа, Русија и Србија: јуче и данас. У Философија и друшйво, 3, 235-257.

Благојевић, М. (2013). Савремена религиозност студената и десекуларизација српског друштва. У Посиисекуларни обрй. Београд.

Grace, D. (2005). Religija u suvremenoj Evropi. Zagreb: Golden marketing Tehnička knjiga.

Ђорђевић, Д. (1984). Беї оg цркве. Књажевац: Нота.

Ђорђевић, J. (2001). Западна цивилизација наставља трагања. У Lakroa, M. New age ideologija Novog doba. Beograd: Klio.

Jukić, J. (1997). Lica i maske svetoga. Загреб: KS.

Kaufman, F-X. (2003). Kako da preživi kršćanstvo?. Zagreb: KS.

Lakroa, M. (2001). New age ideologija Novog doba. Beograd: Klio.

Мандзаридис, Г. (2004). Социолоїија хришћансйва. Београд: ХКЦ.

Mardešić, Ž. (2007). Rascjep u svetome. Zagreb: KS.

Matulić, T. (2009). Metamorfoze kulture., Zagreb: GK.

Релиіиозности у Србији 2010. (2011). Београд: ХКЦ. 


\section{Zoran Krstić}

University of Belgrade, Faculty of Orthodox Theology, Belgrade

\section{Possibilities of Christian Theological Thinking in Postmodernity}

The author tries to answer the question posed in the title of this essay - is 1 it possible, from the Christian position today, even to think theologically about certain problems due to the very strong and quite often imperceptible drift mentality of the postmodern religiosity. Subsequent to the initial highlighting of a difficult position of the Christian theologian, an insight into European secularization, along with the ongoing processes of de-secularization, is being given here, followed by a "return of the holly" into the public sphere. This insight is achieved through the results of a research in religiosity, as in Europe, so is it, even in more detail through the results of the latest survey of religiosity, in Serbia. The author holds that there are certain reasons for optimism, if one compares the current situation with the situation of a few decades ago, but yet, in general, we have to be very careful in our own optimism. The postmodern religiosity does not mean a return to the traditional forms of religiosity, nor even does it mean a return to traditional European churches. As the characteristics of such religiosity, the author emphasizes non-institutionalism and narcissism, asking the question what king of God has come to us. In the concluding reflections an appearing emphasis is that the contemporary situation imposes the question of God as a fundamental theological question, but that theology should not be just talk about God, but rather a God's speech relevant to the specific human existence.

Key words: theologian, secularization and de-secularization, religiosity and the Christian faith, sociography, postmodern religious mentalities.

Датум пријема чланка: 29. 10. 2014.

Датум прихватања чланка за објављивање: 13. 11. 2014. 